\title{
Photographic and Radiograpic Study of Osteological Abnormalities of the Head of Adult African Catfish (Clarias gariepinus)
}

\author{
Estudio Fotográfico y Radiográfico de las Anomalías Osteológicas \\ de la Cabeza del Pez Gato Africano Adulto (Clarias gariepinus)
}

"A. O. Olatunji-Akioye; ${ }^{* *}$ O. K. Adeyemo \& ** O. T. Akomolafe

\begin{abstract}
OLATUNJI-AKIOYE, A. O.; ADEYEMO, O, K. \& AKOMOLAFE, O. T. Photographic and radiograpic study of osteological abnormalities of the head of adult african catfish (Clarias gariepinus). Int. J. Morphol., 28(3):719-722, 2010.

SUMMARY: Radiography is a practical screening tool to detect subtle skeletal abnormalities in the adult catfish. Systematic identification of skeletal abnormalities in vertebrates provides an insight into the pathogenesis of skeletal disorders. In the present study; we conducted a mutagenesis screen for skeletal dysplasias in adult catfish, using photography and radiography to assess abnormalities in skeletal anatomy and bone morphology of the head. Two of the fish had skeletal protuberances on the head, while the third had a skeletal depression on the head with associated jaw deformity. However, there was no spinal involvement or other skeletal abnormalities. This study suggests a need for closer monitoring of cultured fish species; including dietary and nutritional requirements, breeding and exposure to pollution and pollutants.
\end{abstract}

KEY WORDS: Photography; Radiography; Skeletal abnormality; Clarias gariepinus.

\section{INTRODUCTION}

A wide range of developmental events culminates in the final structure and morphology of the adult skeleton. This is evidenced by the variety of genes that are mutated in human skeletal dysplasias. Skeletal abnormalities are a fundamental problem in fish aquaculture, as they decrease the quality of cultured fish by affecting their external morphology, growth, and survival. The majority of the skeletal malformations have been detected and described, especially at the later developmental stages. Only a few studies, describing such abnormalities in adult fish exist. Abnormalities in fishes can have various causes, but are usually considered to originate from mutations and from teratogenic effects of adverse environmental factors, such as mutagenic chemicals in the water. Mutations affecting the earliest patterning events, such as somite segmentation, lead to abnormalities in the adult vertebral column ( $\mathrm{Li}$ et al., 1997). Mutations of transcription factors (el Ghouzzi et al., 1997; Jabs et al., 1993; Lee et al., 1997; Mundlos et al., 1997) or components of extracellular signaling pathways (Gong et al., 1999; Vajo et al., 2000) affect later events of cell differentiation and proliferation, sometimes producing widespread defects in bone growth and maturation. Mutations in components of cartilage or bone matrix also have profound effects on the development of the skeleton (Francomano et al., 1996) and on its response to injury or stress.

Malformations are often associated with growth depression and high mortality rate. Andrades et al. (1996) showed that only a few percent of larvae affected by skeletal (lordotic) malformation can survive after larval development. This leads to significant loss of money for the hatchery. In addition, fish growing with malformations are sold at a depressed price. Abnormalities in fishes have been reported from different parts of the world from time to time (Kaur et al., 1996; Subba, 1998-1999; Subba \& Pandey, 2000-2001). While abnormalities in fish are not uncommon, those of the upper jaw are very rare (Subba, 2004). Skeletal abnormalities have large economical and biological consequences in aquaculture. This paper presents the results of our findings on skeletal abnormalities in cultured table-sized African Catfish Clarias gariepinus (Burchell, 1822).

\footnotetext{
* Department of Veterinary Surgery and Reproduction, Faculty of Veterinary Medicine, University of Ibadan, Ibadan, Nigeria.

** Fish and Wildlife Unit, Department of Veterinary Public Health and Preventive Medicine, Faculty of Veterinary Medicine, University of Ibadan, Ibadan, Nigeria.
} 


\section{MATERIAL AND METHOD}

Three adult Clarias gariepinus showing abnormalities were collected from two separate private farms in Ibadan, Oyo state, Nigeria. They were assessed and determined to be abnormal based on swellings and depressions observed on the head. Morphological changes in the abnormal fishes were studied using linear measurements, photography and radiography. The fish were thereafter preserved in $10 \%$ formalin.

\section{RESULTS}

In the present study, the fish assessed had a total length of $45 \pm 1.41 \mathrm{~cm}$ and girth was $22.5 \pm 0.71 \mathrm{~cm}$. They weighed approximately 550g. Grossly, it was observed that of the three abnormal Clarias heads, two were outward protuberances (Figs. 1-4) whereas the third was a depression (Figs. 5 and 6). The two Clarias gariepinus, which had protuberances on their head, had no further abnormalities (compare with figure 7, which is of a normal adult Clarias gariepanus) whereas the fish with depression had concurrent jaw deformity as well. Radiographically, abnormal skeletal protuberances (Figs. 2 and 4) were better visualised than skeletal depression (Fig.6). All of the three specimens however showed no spinal column involvement in the abnormalities presented when compared with figure 8 , which shows a radiograph of a normal adult fish.

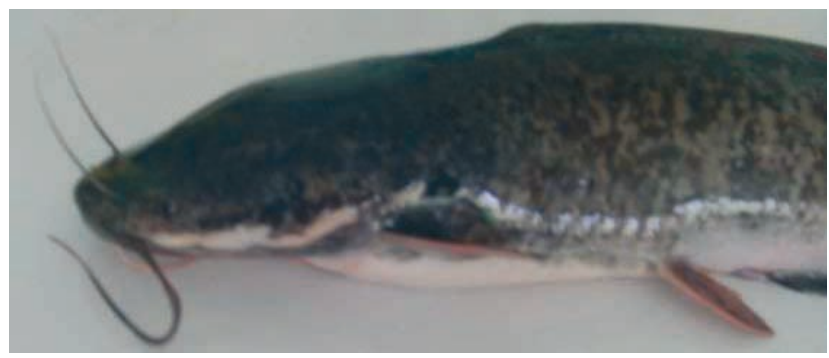

Fig. 1. Clarias gariepinus with skeletal protuberance on the parietal part of the head.

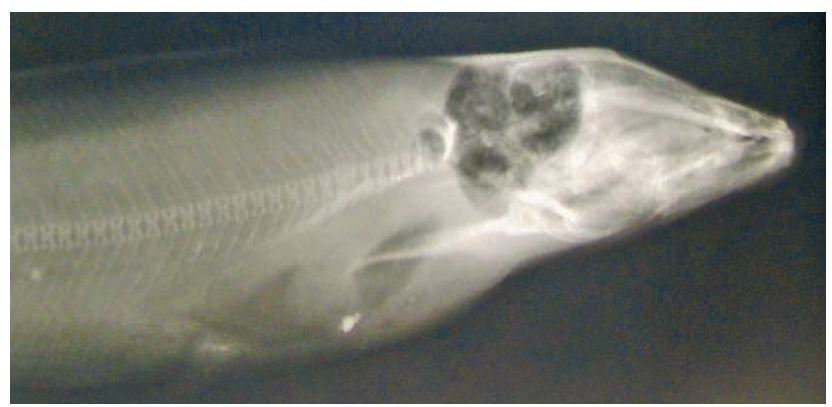

Fig. 2. A radiograph of Clarias gariepinus in Figure 1 showing the details of the skeletal abnormality.

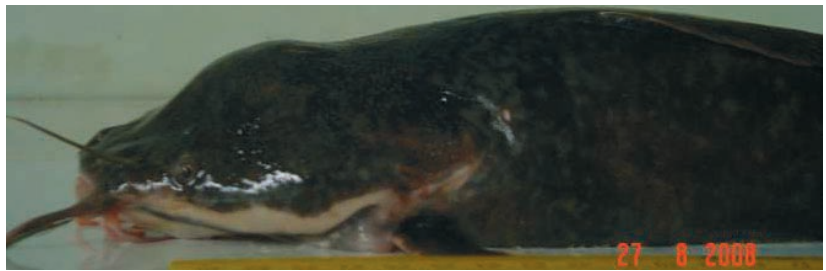

Fig. 3. Clarias gariepinus with skeletal protuberance on the parietal part of the head.

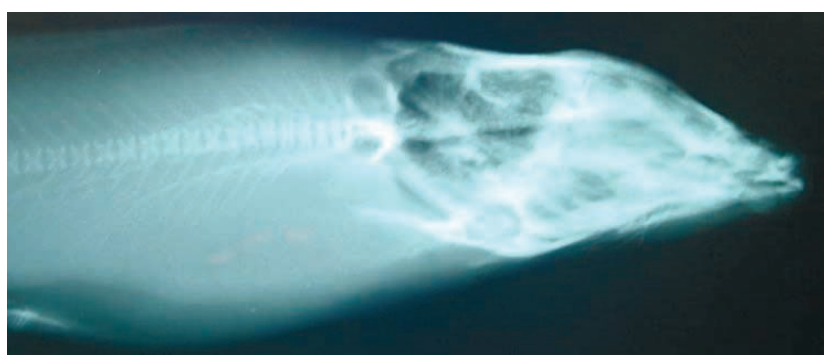

Fig. 4. A radiograph of Clarias gariepinus in Figure 3 showing the details of the skeletal abnormality.

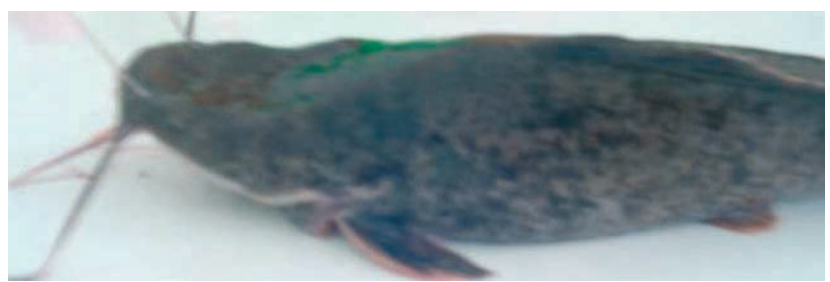

Fig. 5. Clarias gariepinus with a depression on the on the parietal part of the head.

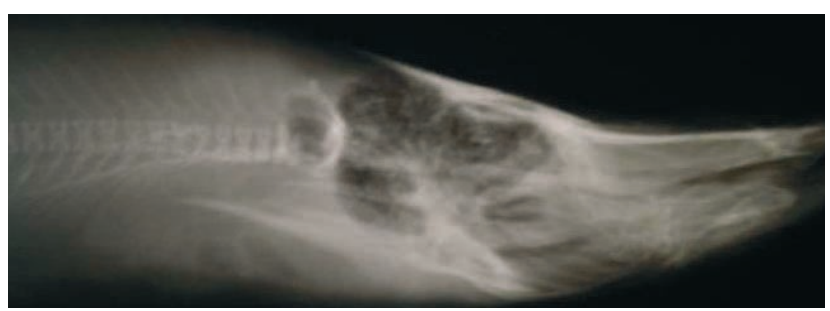

Fig. 6. A radiograph of Clarias gariepinus in Figure 5 showing the details of the skeletal abnormality of the head, which also affected the buccal cavity.

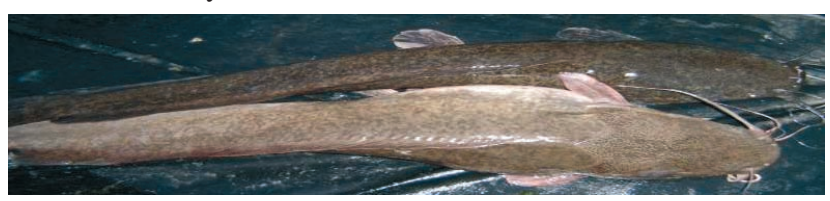

Fig. 7. Normal adult Clarias gariepanus head.

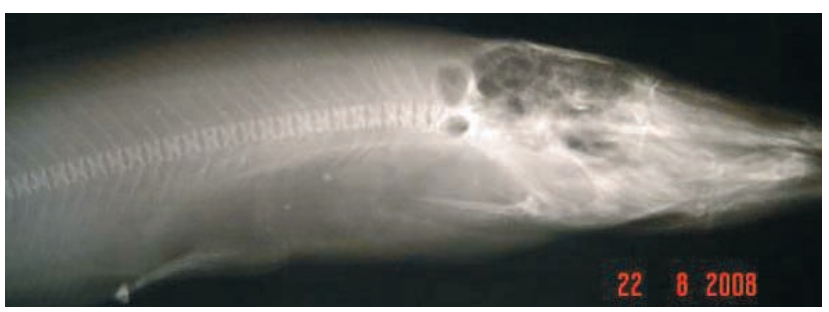

Fig. 8. Radiograph of normal adult Clarias gariepanus shown in figure 7. 


\section{DISCUSSION}

Radiography is faster and simpler to perform than standard histological methods for examining skeletal anatomy and provides considerable details without requiring the sacrifice of the animal. X-rays can also be used as a rapid survey of known mutants of potential interest for skeletal abnormalities. Thus, radiography is a powerful screening tool for the identification of new mutants affecting skeletal development.

Several workers have suggested that different factors are responsible for the different types of abnormalities observed in fish. Conditions, such as parasitic infection, arthritis, tumors, bad nutrition, or a congenital abnormality have all been suggested as causal factors (Heupel et al., 1999). Unfavorable environmental conditions during embryonic development may also be a factor (Mancini et al., 2006). Pollutants have been considered to be responsible for the deformation of different parts of the body of fish. Bengtsson et al. 1985 has suggested injury being other factors for abnormalities. Developmental errors are also responsible for deformation in fishes (Uma \& Waghray 1998-90, Dutta et al., 1993). Dublin, (1979) is of the opinion that deformation in fishes is caused by diseases. The main source of pollution is likely to be storm-water runoff from roofs and roads, which is generally discharged into streams, coastal lake waters, and aquifers. The discharge usually contains lead, zinc, and copper from vehicle brake linings, as well as cadmium from tyres and carcinogenic by-products from petrol and oil (Wilson, 1999). Storm water from rural areas also carries persistent organic pollutants such as the pesticide DDT, which has been implicated as a cause of skeletal deformities in other fish species (Bengtsson et al.). An increased incidence of skeletal deformities among commercial fish species would suggest environmental deterioration and hence signal the need for prompt remedial action. The nature of the dietary protein fraction also affects the quality of fish larvae development. It appears that dietary incorporation of 20 aminoacid peptides or di- and tripeptides leads to a reduction of spinal malformations in sea bass. Among vitamins, the teratogenic effect of retinoic acid is now well documented in vertebrates. High dietary retinoic acid levels result in higher incidence of bone deformities, such as vertebral curvature, central fusion and compression of vertebra in Japanese flounder larvae. The results in this study therefore also call for further studies on dietary factor involvement in the development of skeletal abnormalities.

OLATUNJI-AKIOYE, A. O.; ADEYEMO, O, K. \& AKOMOLAFE, O. T. Estudio fotográfico y radiográfico de las anomalías oteológicas de la cabeza del pez gato africano adulto (Clarias gariepinus). Int. J. Morphol., 28(3):719-722, 2010.

RESUMEN: La radiografía es una herramienta práctica de la investigación que fue utilizada para detectar sutiles alteraciones esqueléticas en el pez gato adulto. La identificación sistemática de las anomalías esqueléticas de los vertebrados da una idea de la patogénesis de los trastornos esqueléticos. En el presente estudio, se realizó una pantalla de mutagénesis de displasias esqueléticas en el pez gato adulto, utilizando la fotografía y la radiografía para evaluar las anomalías en la anatomía del esqueleto y la morfología ósea de la cabeza. Dos de los peces tenían protuberancias óseas en la cabeza, mientras que el tercero tenía una depresión ósea en la cabeza asociada a deformidades de la mandíbula. Sin embargo, no hubo participación de la columna vertebral u otras anomalías esqueléticas. Este estudio sugiere la necesidad de una vigilancia más estrecha de las especies de peces cultivados, incluyendo dietética, nutrición, reproducción y exposición a la contaminación y los contaminantes.

PALABRAS CLAVE: Fotografía; Radiografía; Anomalías osteológicas; Clarias gariepinus.

\section{REFERENCES}

Andrades, J.; Becerra, J. \& Fernandez-Llebrez, P. Skeletal deformities in larval, juvenile and adult stages of cultured gilthead sea bream (Sparus aurata L.). Aquaculture, 141:1-11, 1996.

Bengtsson, B. E.; Bengtsson, A. \& Hinberg, M. Fish deformities and pollution in some Swedish waters. Ambio, 14:32-5, 1985.
Burchell. In: Catalog of Fishes, Special Publication of the Center for Biodiversity Research and Information. Eschmeyer, W. N. (eds). San Francisco California Academy of Sciences, 1822.

Dublin, M. Fish Disease. New York, TFH Publication Inc., 1979. p.93. 
Dutta, S. P. S.; Sharma, J. \& Kaul, V. A truncated specimen of Garra lamta (Ham). J. Natcon., 5(2):115-6, 1993.

el Ghouzzi, V.; Le Merrer, M.; Perrin-Schmitt, F.; Lajeunie, E.; Benit, P.; Renier, D.; Bourgeois, P.; Bolcato-Bellemin, A. L.; Munnich, A. \& Bonaventure, J. Mutations of the TWIST gene in the Saethre-Chotzen syndrome. Nat. Genet., 15:42-6, 1997.

Francomano, C. A.; McIntosh, I. \& Wilkin, D. J. Bone dysplasias in man: Molecular insights. Curr. Opin. Genet. Dev., 6:301-8, 1996.

Gong, Y.; Krakow, D.; Marcelino, J.; Wilkin, D.; Chitayat, D.; Babul-Hirji, R.; Hudgins, L.; Cremers, C. W.; Cremers, F. P.; Brunner, H., G.; Reinker, K.; Rimoin, D. L.; Cohn, D. H. \& Goodman, F. R. Heterozygous mutations in the gene encoding noggin affect human joint morphogenesis. Nat. Genet., 21:302-4, 1999.

Heupel, M. R.; Simpfendorfer, C. A. \& Bennet, M. B. Skeletal deformities in elasmobranch from Australian water. J. Fish Biol., 54:1111-5, 1999.

Jabs, E. W.; Müller, U.; Li, X.; Ma, L.; Luo, W.; Haworth, I. S.; Klisak, I.; Sparkes, R.; Warman, M. L.; Mulliken, J. B.; et al. A mutation in the homeodomain of the human MSX2 gene in a family affected with autosomal dominant craniosynostosis. Cell, 75:443-50, 1993.

Kaur, H.; Kaul, V. \& Dutta, S. P. S. Deformities in some freshwater fishes of Jammu. J. Freshwater Biol., 18(4): 213-21, 1996.

Lee, B.; Thirunavukkarasu, K..; Zhou, L.; Pastore, L.; Baldini, A.; Hecht, J.; Geoffroy, V.; Ducy, P. \& Karsenty, G. Missense mutations abolishing DNAbinding of the osteoblast-specific transcription factor OSF2/CBFA1 in cleidocranial dysplasia. Nat. Genet., 16:307-10, 1997.

Li, Q. Y.; Newbury-Ecob, R. A.; Terrett, J. A.; Wilson, D. I.; Curtis, A. R.; Yi, C. H.; Gebuhr, T.; Bullen, P. J.; Robson, S. C.; Strachan, T.; Bonnet, D.; Lyonnet, S.; Young, I. D.; Raeburn, J. A.; Buckler, A. J.; Law, D. J. \& Brook, J. D. Holt-Oram syndrome is caused by mutations in TBX5, a member of the Brachyury (T) gene family. Nat. Genet., 15:21-9, 1997.

Mancini, P. L.; Casas, A. L. \& Amorim, A. F. Morphological abnormalities in a blue shark Prionace glauca (Chondrichthyes: Carcharhinidae) foetus from southern Brazil. J. Fish Biol., 69:1881-4, 2006.
Mundlos, S.; Otto, F.; Mundlos, C.; Mulliken, J. B.; Aylsworth, A. S.; Albright, S.; Lindhout, D.; Cole, W. G.; Henn, W.; Knoll, J. H.; Owen, M. J.; Mertelsmann, R.; Zabel, B. U. \& Olsen, B. R. Mutations involving the transcription factor CBFA1 cause cleidocranial dysplasia. Cell, 89:773-9, 1997.

Subba, B. R. \& Pandey, M. R. A truncated specimen of Mrigal fish inhabiting river Koshi. Nepal. J. Inst. Agri. Anim. Sci., 21-22:245-9, 2000-2001.

Subba, B. R. Multiple abnormalities in African catfish. $J$. Inst. Agri. Anim. Sci., 19-20:187-91, 1998-1999.

Subba, B. R. Anomalies in bighead carp Aristichthys nobilis and African catfish Clarias gariepinus in Biratnagar, Nepal. Our Nature, 2:41-4, 2004.

Uma, S. \& Waghray, A. Abnormality in the brackish water fish, Macrograthus aculeatus (Bloch). Matsya, 15-6: 169-70, 1989-1990.

Vajo, Z.; Francomano, C. A. \& Wilkin, D. J. The molecular and genetic basis of fibroblast growth factor receptor 3 disorders: The achondroplasia family of skeletal dysplasias, Muenke craniosynostosis, and Crouzon syndrome with acanthosis nigricans. Endocr. Rev., 21:23$39,2000$.

Wilson, T. Catchment 22. Metro, 214:53-9, 1999.

Correspondence to:

Dr. Adenike O. Olatunji-Akioye

Department of Veterinary Surgery and Reproduction

Faculty of Veterinary Medicine

University of Ibadan

Ibadan

NIGERIA

Tel: +234-803-409-1407

Email: bonik2001@yahoo.com aoo.akioye@mail.ui.edu.ng

Received: 07-07-2009

Accepted: 18-02-2010 